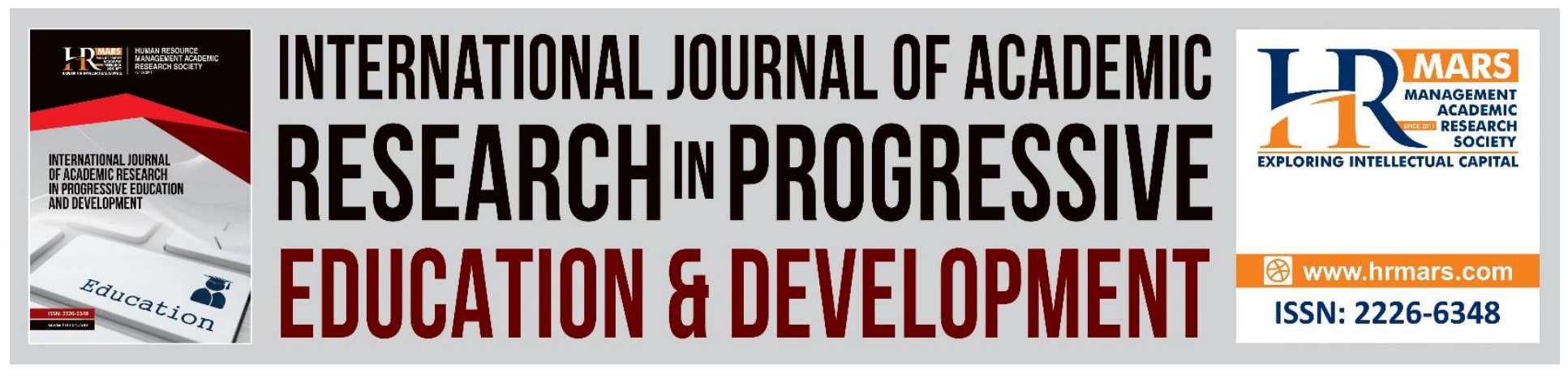

\title{
The Application of Mind Stimulus Card in Malay Language Learning Towards the Development of Student's Teamwork Skills
}

Nor Samsiyah M. Horsi, Siti Suraiyah M. Horsi, Ikhsan Othman

To Link this Article: http://dx.doi.org/10.6007/IJARPED/v9-i2/7491 DOI:10.6007/IJARPED/v9-i2/7491

Received: 11 April 2020, Revised: 16 May 2020, Accepted: 11 June 2020

Published Online: 25 July 2020

In-Text Citation: (Horsi et al., 2020)

To Cite this Article: Horsi, N. S. M., Horsi, S. S. M., \& Othman, I. (2020). The Application of Mind Stimulus Card in Malay Language Learning Towards the Development of Student's Teamwork Skills. International Journal of Academic Research in Progressive Education and Development, 9(2), 473-482.

Copyright: (C) 2020 The Author(s)

Published by Human Resource Management Academic Research Society (www.hrmars.com)

This article is published under the Creative Commons Attribution (CC BY 4.0) license. Anyone may reproduce, distribute, translate and create derivative works of this article (for both commercial and non-commercial purposes), subject to full attribution to the original publication and authors. The full terms of this license may be seen at: http://creativecommons.org/licences/by/4.0/legalcode

Vol. 9(2) 2020, Pg. 473 - 482

http://hrmars.com/index.php/pages/detail/IJARPED JOURNAL HOMEPAGE

Full Terms \& Conditions of access and use can be found at http://hrmars.com/index.php/pages/detail/publication-ethics 


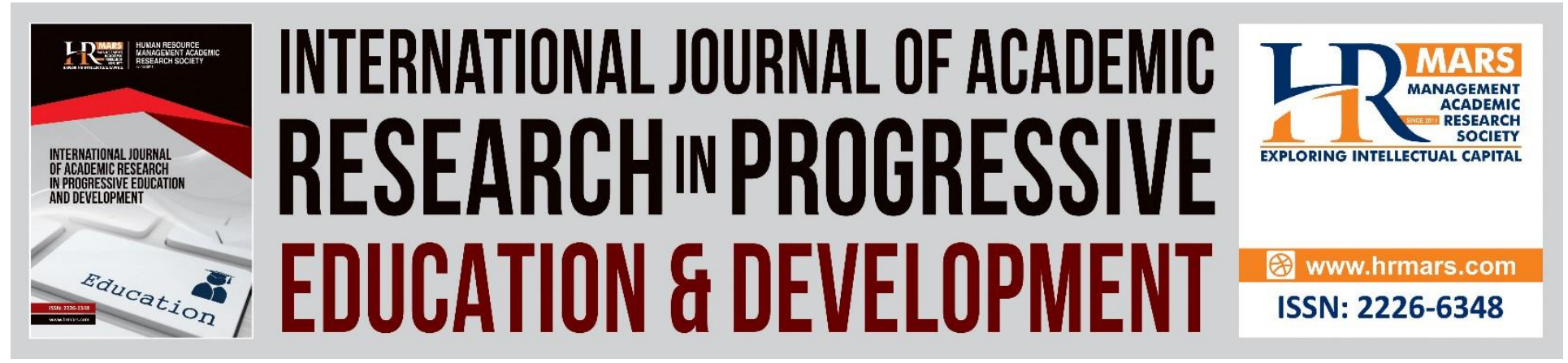

\title{
The Application of Mind Stimulus Card in Malay Language Learning Towards the Development of Student's Teamwork Skills
}

\author{
Nor Samsiyah M. Horsi, Siti Suraiyah M. Horsi, Ikhsan Othman \\ Faculty of Education and Human Development, Universiti Pendidikan Sultan Idris, \\ 35900 Tanjung Malim, Perak, Malaysia
}

\begin{abstract}
The application of soft skills in the Malay language subject is one of the cross-curriculum approach that must be implemented by the in their teaching and learning process. Soft skills are included of seven elements; communication skills, creative thinking skills, continuous learning, teamwork, leadership, ethical and moral skills, and entrepreneurial skills. Through the seven elements of skills, researcher has selected the teamwork skills by applying the mind stimulus card that has been used in the Malay language lesson. Based on the Malaysia Education Blueprint 2013-2025, the Ministry of Education has outlined a number of learning features that must be obtained by the students. Therefore, researcher has developed the mind stimulus card to examine the development of the team work skills in four different schools. The process of collecting data is done by using the observation method. The observations were conducted on the 75 students that have been selected as the respondent in this study. The finding showed that the development of the students' teamwork was at the high level. In conclusion, the application of the mind stimulus card in the Malay language lesson was able to enhance the development of the student's teamwork.
\end{abstract}

Keywords: Soft Skills, Malay Language, Mind Stimulus Card, Teamwork Skills.

\section{Introduction}

The application of soft skills in the Malay language teaching is important and being one of the agenda in the field of education through the Malaysia Education Blueprint (MEB, 2013-2025). This proves that the quality of the curriculum in Malaysia is often reinforced for the future generations from time to time to provide the opportunity for student development (PPPM, 20132015). Saedah (2015) stated that the curriculum is the prime of educational development for young people competing in the country's advance development. In this regard, the curriculum is seen as the most important agenda to build and shape the future of the nation globally. 
National Education Philosophy comprises of six elements; knowledge, leadership skills, thinking skills, ethics and spirituality, bilingual skills, and national identity as contained in the Malaysia Education Blueprint (2013-2025). According to Sufean (2004) the process of teaching and learning in the classroom should be focus on the learning that is interesting for the curriculum development. These changes need to be driven by talented people, especially knowledgeable leaders and workers, with other inputs, such as sufficient manpower and capital. Malaysia needs to have a competitive education system to produce more competitive talent internationally. Malaysia's aimed is to be an economically advanced, technologically, and modernized standard of living in line with the 2020's vision.

\section{Background}

Educational transformation needs to involve many parties whether directly or indirectly involved in education. In fact, education needs to be kept up to date with the changes and developments of the future (Bahagian Pengurusan Sekolah Harian, 2015). Teachers need to be prepared for the changes and to be able to effectively manage the teaching and learning implemented to meet the needs of today's students. Teachers need to be aware and willing to make changes in teaching and learning in line with 21st century learning. The pioneering 21st-century learning initiative was launched in 2014 by the Ministry of Education and has develop throughout the country beginning in 2015 .

Educators cannot avoid teaching tasks. Good teaching needs to be planned with syllabus preparation of annual calendar followed by the preparation of daily lesson plans. A teacher who wishes to teach must make plans in advance of the subject to be delivered, the objectives to be achieved, the activities to be carried out during the lesson, and the results or reflections of the lesson (Surat Perkeliling Ikhtisas: No. 8/1990, No. 6/1991, No. 7/1994, and No. 10/1995). According to Norsita and Zainal (2014), teachers need to be aware that attitudes play an important role in determining the preparation, preparation of the stimulus materials and teachers' emotions will influence teaching, emotional and learning styles. Thus, the use of teaching tools is one of the most important aspects of creating a learning experience (Tyler, 1950).

Teachers often use existing teaching methods to transform into teaching that is innovative (Arniza \& Zamri, 2018). This is important because, innovative teachers should come up with more ideas to enhance their teaching in the classroom. Therefore, various curriculumbased guidelines should be designed to guide teachers in implementing teaching and learning. Researcher has developed the mind stimulation materials cards aim for Malay language and the development team skills of students. Teachers need to diversify their teaching into the classroom in order to interest students and to achieve the educational aspirations of 21st century learning. This 21st-century teaching implementation should focus on students and teachers only as facilitators in their teaching (PPPM, 2013-2025). According to Habib (2008) teachers need to change existing ways of teaching and improve teaching methods by applying value added skills. 
According to Suppiah (2013) the use of graphs, diagrams, drawings, flow charts and sketches in teaching can enhance cognition processing through simultaneous visual and verbal techniques. Therefore, the use of these interesting materials can interest students in the development of their knowledge. Many researchers have done some research on the subjects they teach. Given that the subjects in the curriculum are very wide, the researchers have selected subjects taught in the Malay language to use mind stimulation materials for the development of teamwork skills among students. This is important because the Malay language is the language of communication, the language of unity, and widely used language in curriculum in Malaysia (Pelan Induk Pendidikan, 2006-2010).

Various skills have been suggested by the Ministry of Education Malaysia for students to master. However, researchers have chosen soft skills as an element of teamwork as these skills have been developed at Institutions of Higher Learning but are still poorly implemented at school level (Arniza \& Zamri, 2018). At the school level, soft skills or better known as added value skills are implemented with little modification or modification of the concept of soft skills. The added value skills are the skill acquired through the application of generic skills through specific approaches, techniques and methods of teaching and learning in the classroom. However, these skills have not been fully implemented in accordance with the Malaysian Education Development Plan which includes the essential elements of communication skills, critical thinking and problemsolving skills, continuous learning, teamwork, ethics and morals, teamwork, and entrepreneurial skills as needed Malay language learning process (Arniza \& Zamri, 2018).

Alkendele (2012) in her study found that students are aware that through teamwork, they can improve communication with classmates, communicate with peers of different nationalities and strengthen mutual trust in team members. Luca and Tarricone (2002) conclude that most students are aware of the need to commit to teamwork, share ideas and new information during teaching and learning, take responsibility for the team, and solve problems together to succeed in the team through their learning practices. Teamwork skills will also see good relationships between team members throughout the lesson using the stimulus materials mind-blowing cardboard. Next, each team member has the ability to contribute to the planning and coordination of their group work. Teamwork skills refer to students not only learning good work habits and producing high quality work, but they actually enjoy a good teamwork experience through teaching and learning.

Teamwork skills are the ability for people to work together to achieve the same goals as others with different cultural backgrounds and social backgrounds (UPSI, 2007). Therefore, teamwork can be achieved when one is able to effectively build good relationships and relationships with others to achieve the same objectives. In addition, teamwork skills require all team members to understand and exchange alternate roles between leaders and members to produce a given task. All members and team leaders need to understand and cooperate with each other attitudes, behaviours to enable them to contribute to the planning. Team members also need to trust each other in teamwork. As such, they will be able to make decisions quickly, 
use their discretion wisely and develop their own talents and potentials to facilitate for quality process (KPM, 2018).

\section{Problem Statements}

Studies on the application of teamwork skills in the curriculum of a subject are still at a moderate level. The application of soft skills is needed across the curriculum and a subject must contain elements of teamwork skills to help students develop their potential and relate to one another. Although many studies have been conducted on soft skills at university, studies on the application of soft skills at the secondary level are still lacking (Arniza \& Zamri, 2018). Besides soft skills are not directly stated in the curriculum but, all seven elements of soft skills are stated in KSSM to be absorbed by the Malay Language teachers (MOE 2016).

Soft skills or value-added skills are very important because they are embedded in 21st century educational features (PPPM, 2013-2025) but are not explicitly implemented (Arniza \& Zamri, 2018). This is because teachers are sometimes aware of the existence of these soft skills but in practice they are less clear on their use (Abdullah, 2006). Based on teaching practice since 2003, Abdullah (2006) stated that trainee teachers do not know how to absorb soft skills or value added skills. Teachers also do not understand how to apply soft skills in the classroom, causing the presence of these skills to be underestimated at the school level and because soft skills are feared to delay PdP time if implemented by teachers (Faizullah, 2014).

In the challenge of this era of globalization, people are racing towards success in life (PPPM, 2015). As such, teamwork is an approach that helps both parties to achieve something. In order to meet the aspiration of the Ministry of Education Malaysia, all students should be emphasized on the importance of teamwork skills. But lately, each can be seen as acting individually to achieve their goals in education or career. It is this study, mind stimulating materials should be used as an indicator to observe teamwork between students.

\section{Research Objectives}

The objectives of this study are:

1. to exploring the application of teamwork skills in teaching Malay language.

2. to assess the application of the mind stimulation card in teaching Malay Language affecting development of teamwork skills among students.

\section{Research Questions}

Some research questions developed by the researcher are as follow:

1. to what extent the application of teamwork skills in teaching Malay language?

2. to what extent the stimulus card application in mind teaching Malay language to the development of teamwork skills of students?

\section{The Tyler Curriculum Model 1950}

Tyler's (1950) curriculum model outlines how one lesson is designed for the right purpose of learning. In building the curriculum and teaching, according to Tyler there are four questions that 
Vol. 9, No. 2, 2020, E-ISSN: 2226-6348 @ 2020 HRMARS

need to be addressed at the basic level for a teaching goal to be achieved. Four questions need to be developed to ensure that the teaching objectives are met:

a. What is the purpose or goal of the lesson to be achieved?

b. What lessons do you need to teach in order to achieve that goal?

c. How to handle that learning experience effectively?

d. How to determine one's goals or aims achieved?

The diagram below explains the basic principal of the Tyler model.

Diagram 1: The Tyler Model

\section{Stating Objectives}

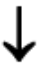

Selecting Learning Experiences

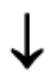

Organising Learning Experiences

$\downarrow$

\section{Evaluation}

1. Learning Objectives. In designing the teaching and learning in the Malay Language is necessary to determine the teaching objectives. Therefore, any PDP executed requires goals to achieve the objectives conducted to students.

2. Curriculum Content. Implementing the teaching and learning based on the choice of teaching and syllabus is essential. The content of the curriculum should be organized by organizing the curriculum materials into smaller units, in order from simple to more complex. The arrangement is to facilitate learning.

3. Teaching Methods. The choice of teaching methods and techniques that are appropriate to the topic of learning is essential in order to obtain the best results for students to understand the objectives of the teaching. Through textbook teaching methods and teaching aids it is necessary to ensure that the learning goals are met.

4. Learning Assessment. Once the teaching and learning is implemented, the success of teaching based on the learning objectives should be carried out to the students through examinations. 
Assessments can be formative or summative. In addition, teachers can also conduct action research on the teaching and learning that has been implemented.

Through Tyler's model, the researchers has produce innovations in Malay language using the four basic principles of the model, starting with teaching objectives to be achieved in the development of teamwork skills, researchers determine the content of teaching curriculum to be achieved based on the objectives that have been built, so researchers have chosen teaching methods that utilize the mind-blowing card activity that includes teamwork skills and, finally, assesses learning outcomes by conducting tests for students to determine the level of development of student-team work skills in the subjects during the teaching and learning process.

\section{Method of Study}

The selection of research design is very relevant to be controlled and conducted in this study. This is because an understanding of a subject can be done in detail and precisely to form a purpose (Faridah, Rohaida \& Abd Razak, 2013). Research also offer the opportunity to clearly understand the social and cultural contexts that draw upon aspects of human thought, experience, and understanding rather than the mere attempt to link causal variables alone (Denzin \& Lincoln, 2008). Research is conducted in the natural setting and the researcher is a key instrument in collecting data either in the form of pictures or words, analyzing inductively, focusing on the meaning expressed by the respondent in expressive language and displaying the participant's voice in text. Qualitative research methods have several approaches but are often misinterpreted by the public that qualitative studies use only one approach (Othman Lebar, 2017).

In the early years researchers have developed the mind stimulus card before the teaching and learning. The stimulus card has undergone several tests before being used in teaching. Further, researchers have developed lesson plans that incorporate mind-stimulating card activity in teaching. The study was a qualitative study in which researchers conducted a study of 75 students learning using memory stimulus cards in three schools. Subsequently, the semistructured interview method was based on nine students and three teachers selected as respondents. Finally, the analysis of the document is based on the results of the observation rubric obtained by the teacher throughout the lesson to see the development of teamwork skills. The instruments used in this study were observation checklists, structured interview questions and formative tests. The findings show that mind-stimulating material cards enhance student teamwork.

\section{Findings}

The analysis showed that the application of this mind stimulus card is applicable for the student team work skills. To answer this research question, researchers have collected data through observation. The data were analyzed and displayed as follows. 
Vol. 9, No. 2, 2020, E-ISSN: 2226-6348@ 2020 HRMARS

\section{Observation Insights (Teamwork Skills)}

Observations have been made by three senior teachers during teaching Malay language using mind stimulation materials carried by the teachers involved in the study of three schools. The observation is based on the teamwork skills that occurred during the teaching and learning session. The observation results are summarized as in Table 1.

Table 1: Observations on the Development of Teamwork Skills (Student)

\begin{tabular}{|c|c|c|c|c|}
\hline Team work skill & $\begin{array}{c}\text { Observer } 1 \\
\text { (Team work) }\end{array}$ & $\begin{array}{l}\text { Observer } 2 \\
\text { (Team work) }\end{array}$ & $\begin{array}{l}\text { Observer } 3 \\
\text { (Team work) }\end{array}$ & Conclusions \\
\hline Just know & 0 & 0 & 0 & 0 \\
\hline To know & 0 & 0 & 3 & 3 \\
\hline $\begin{array}{l}\text { Task with } \\
\text { instruction }\end{array}$ & 2 & 3 & 3 & 8 \\
\hline $\begin{array}{l}\text { Task without } \\
\text { instruction }\end{array}$ & 23 & 22 & 19 & 64 \\
\hline Min & 25 & 25 & 25 & 3.81 \\
\hline
\end{tabular}

(Scale: 1.00=Low, 2.34=medium, 3.67=High)

Based on Table 1 were found to be the mean average of the development of teamwork skills of students in the teaching and learning of Malay develop soft skills using stimulus material mind is 3.81 which is at a high level. Pupils can do teamwork without the teacher's instructions. They can already understand the questions asked through the use of the mind stimulus card. In conclusion, the usage of the card in the mind stimulation materials in teaching Malay language can improve student element teamwork skills at a high level.

\section{Discussion and Summary}

To summarize, the results of the analysis relating the mind stimulus card usage in teaching Malay language excite students. This learning style makes pupils more understanding, confident, and more enjoyable to learn (KPM, 2017). It happened s because all students able to demonstrate positive behavior throughout the lesson. Pupils also show good teamwork with other members. Teamwork gives students of various races the opportunity to sit in groups and discuss their ideas.

According to Alkendele (2012) the study, students are aware that through teamwork, they able to improve communication with classmates, communicate with peers of different races and strengthen each other's confidence among team members. Students achieve better in their group assignments. Students need to be emphasize the importance of teamwork in their daily 
lives. In addition, the elements of teamwork can also enhance students' soft skills. The mind stimulus card used is enjoyable when students are able to express their emotions either through feedback.

From the findings of this study, noted it may cause the pupils not to sleep during the course of the teaching and learning because they can interact with each other. Teachers can easily implement the teaching and learning using a the mind-blowing card in addition to the guidance provided while students able to see the resulting cards in the form of interesting pictures and the task they need to complete. The benefits of a mind-blowing card have impacted students' emotional, knowledge, and behavioral skills. This finding is consistent with studies Nik Nor Ahmarizam (2015), if teaching is less attractive then teachers should find approaches, methods, strategies and techniques of teaching new disciples so student will develop interest to the learning process.

The exposure of this study incorporates elements of teamwork skills through the mind stimulus card is an innovation that teachers can cooperate in their teaching. In future, teachers should focus on better materials for the development of teamwork skills. The development of teamwork skills should also be practiced from the school days so that students can apply it in their lives whether it be with their neighbors, their organization and others.

\section{Conclusion}

Based on this study, the mastery of information transfer skills in Malay language has related to the continuous learning. This is because the students who were able to master the information transfer skills such as grammar managed to enhance their vocabulary in Malay language continuously so that they could use the proper grammar formally or informally. Despite of that, students who were able to master the information transfer skills managed to explain the literature aspect correctly. In addition, the mastery of information transfer in writing will help the students to apply this skills in the classroom, higher education and employment sectors. This is also same with interpreting information by using the information transfer skills in the text. The mastery also related to the students' ability in reasoning the information given. Therefore, all the information transfer aspect must be learned continuously to enhance one's achievement whether in education or career field.

\section{Corresponding Author Email}

norsham8034@gmail.com

\section{References}

Abdullah, H. (2006). Ulasan kritis terhadap pengajaran kemahiran bernilai tambah. DIm. Idris Mohd Radzi \& Dahlia Janan (pnyt.). Mengajar dan Belajar Bahasa Melayu: Penerapan Kemahiran Bernilai Tambah, hlm. 1-11. Tanjong Malim: Penerbit Universiti Pendidikan Sultan Idris.

Alkendele, D. O. (2012). Enhancing teamwork and communication skills among first year students at the University Botswana. TESOL Journal, 6(1), 2-15. 
INTERNATIONAL JOURNAL OF ACADEMIC RESEARCH IN PROGRESSIVE EDUCATION AND

DEVELOPMENT

Vol. 9, No. 2, 2020, E-ISSN: 2226-6348 @ 2020 HRMARS

Arniza, M., \& Zamri, M. (2018). Kemahiran bernilai tambah: Teori dan Amali. Bangi, Selangor: Universiti Kebangsaan Malaysia.

Bahagian Pengurusan Sekolah Harian. (2015). Buletin Anjakan Transformasi Pendidikan Malaysia: Pelan Pembangunan Pendidikan Malaysia 2013-2025. Kuala Lumpur: Kementerian Pendidikan Malaysia.

Denzin, N. K., \& Lincoln, Y. S. (2008). The landscape of qualitative research. Thousand Oaks, CA: SAGE Publications Inc.

Faridah, D., Rohaida, S., \& Abd. Razak, Z. (2013). Transformasi guru dalam pengajaran dan pembelajaran mengenai kemahiran membuat hipotesis dalam kalangan murid sekolah rendah. Jurnal Kurikulum \& Pengajaran Asia Pasifik (JUKU), 1 (3): 47-57.

Habib, M. S. (2008). Memperkasa kesediaan guru melaksanakan perubahan kurikulum di sekolah: Satu perbincangan. Dalam Nik Aziz Nik Pa \& Noraini Idris (pnyt.). Perjuangan memperkesakan pendidikan di Malaysia: Pengalaman 50 tahun merdeka, hlm. 405-424. Kuala Lumpur: Utusan Publication \& Distributors.

Kementerian Pendidikan Malaysia. (1999b). Penyediaan rekod pengajaran dan pembelajaran. Surat Pekeliling Ikhtisas Bil. 12/1999. Kuala Lumpur: Kementerian Pendidikan Malaysia

Kementerian Pendidikan Malaysia. (2015). Pelan Pembangunan Pendidikan Malaysia 2015 2025 (Pendidikan Tinggi). Putrajaya, Malaysia: Kementerian Pendidikan Malaysia.

Kementerian Pendidikan Malaysia. (2017). Pelan Hala Tuju Pendidikan Bahasa Melaayu 20162025. Bahagian Perancangan dan Penyelidikan Dasar Pendidikan. Putrajaya, Malaysia: Firdaus Prees Sdn. Bhd.

Luca, J., \& Tarricone, P. (2002). Successful teamwork: A Case Study. HERDSA. Australia: Edith Cowan University.

Faizullah, M. (2014). Penerapan kemahiran insaniah dalam konteks membina insan berkepimpinan di kalangan murid melalui aktiviti kokurikulum di Universiti. Batu Pahat: Penerbit Universiti Tun Hussein Onn Malaysia.

Ahmarizam, N. N. A. (2015). Pendidikan kelas abad ke-21. Sinar Online. Dicapai daripada http://www.sinarharian.com.my/karya/pendapat/pendidikan-kelas-abad-ke-211.367783.

Norsita, A., \& Zainal, M. (2014). Tinjauan awal interaksi guru kanak-kanak dalam pemupukan pemikiran kreatif kanak-kanak prasekolah. Proceeding of the Social Sciences Research ICSSR 2014.

Othman, L. (2017). Penyelidikan kualitatif: Pengenalan kepada Teori dan Metod. Tanjung Malim: Penerbit Universiti Pendidikan Sultan Idris.

Saedah, S. (2015). Kurikulum masa depan. (2nd ed.). Kuala Lumpur, Malaysia: Universiti Malaya.

Sufean, H. (2004). Pendidikan di Malaysia: Sejarah, sistem dan falsafah. Kuala Lumpur, Malaysia: Dewan Bahasa dan Pustaka.

Suppiah, N. (2013). Proses Kognisi dan afeksi: Kaedah pedagogi hermeneutik dan interpretasi. Tanjong Malim: Penerbit Universiti Pendidikan Sultan Idris.

Tyler, R. W. (1950). Basic principles of curriculum and instruction. Chicago: University of Chicago Press.

Universiti Pendidikan Sultan Idris. (2007). Pandungan Pembangunan Kemahiran Insaniah Universiti Pendidikan Sultan Idris. Tanjong Malim: Universiti Pendidikan Sultan Idris. 